\title{
SISTEM INFORMASI PENGELOLAAN PRODUK DAN JASA BERBASIS WEB PADA UNIVERSITAS NEGERI PADANG
}

\author{
Mutiara Pertiwi ${ }^{1}$ \\ Denny Kurniadi ${ }^{2}$ \\ Yeka Hendriyani $^{3}$
}

\begin{abstract}
This research aims to develop information systems that can accommodate the State University of Padang's asset management, both in the form of products/results of the work of the civitas and services that are held internally or from outside parties who cooperate with the State University of Padang. The system is expected to facilitate the civitas academica in the business development and to promote the products and services based on their categories. The design of the management information systems products and services are built using waterfall model and the design pattern of e-commerce with modeling UML (Unified Modelling Language). The main programming language used PHP (PHP Hypertext Preprocessor), as well as the CSS (Cascading Style Sheets) and Javascript as an additional language with MySQL as a Database Management System (DBMS). The systems are built using codeigniter framework with the architecture of MVC (Model View Controller). The result of the system can be used for the management of products and services, rental booking management, stakeholder cooperation, management of test quality, up to the management of the transaction. The whole of the activities that occur on the system can be documented according to user's needs.
\end{abstract}

Keywords: Information System, service quality product, codeigniter.

\footnotetext{
${ }^{1}$ Mahasiswa Prodi Pendidikan Teknik Informatika

2. Dosen Jurusan Teknik Elektronika Universitas Negeri Padang

3. Dosen Jurusan Teknik Elektronika Universitas Negeri Padang
} 


\section{INTI SARI}

Penelitian ini bertujuan untuk mengembangkan sistem informasi yang dapat mengakomodir manajemen aset Universitas Negeri Padang, baik dalam bentuk produk / hasil kerja dari civitas dan layanan yang diselenggarakan secara internal maupun dari pihak luar yang bekerjasama dengan Universitas Negeri Padang.. Sistem ini diharapkan dapat memfasilitasi civitas academica dalam pengembangan bisnis dan untuk mempromosikan produk dan layanan berdasarkan kategori mereka. Desain produk dan layanan sistem informasi manajemen dibangun menggunakan model waterfall dan pola desain e-commerce dengan pemodelan UML (Unified Modeling Language). Bahasa pemrograman utama yang digunakan PHP (PHP Hypertext Preprocessor), serta CSS (Cascading Style Sheets) dan Javascript sebagai bahasa tambahan dengan MySQL sebagai Database Management System (DBMS). Sistem ini dibangun menggunakan framework codeigniter dengan arsitektur MVC (Model View Controller). Hasil dari sistem dapat digunakan untuk pengelolaan produk dan layanan, manajemen pemesanan sewa, kerjasama pemangku kepentingan, pengelolaan kualitas pengujian, hingga pengelolaan transaksi. Seluruh aktivitas yang terjadi pada sistem dapat didokumentasikan sesuai dengan kebutuhan pengguna.

Kata Kunci: Sistem Informasi, kualitas layanan, produk, codeigniter. 


\section{PENDAHULUAN}

Sistem informasi merupakan sekumpulan komponen yang saling berhubungan untuk mengumpulkan, mengolah, menyimpan dan mendistribusikan informasi, untuk mengambil keputusan dan pengawasan dalam suatu organisasi[4]. Peran sistem informasi dalam suatu organisasi cukup penting mengingat kemudahan serta keamanan yang ditawarkan.

Produk merupakan segala sesuatu yang dapat ditawarkan produsen untuk diperhatikan, diminta, dicari, dibeli, digunakan, atau dikonsumsi pasar sebagai pemenuhan kebutuhan atau keinginan pasar yang bersangkutan[5]. Produk yang dimaksud dalam sistem yang akan dibangun adalah segala bentuk karya/alat yang dihasilkan oleh mahasiswa dan civitas akademika lainnya. Karya/alat ini dapat berupa hasil tugas akhir non-skripsi yang diciptakan dan/atau dikembangkan oleh mahasiswa maupun tidak.

Sedangkan jasa merupakan setiap tindakan atau kegiatan yang dapat ditawarkan oleh satu pihak kepada pihak lain, pada dasarnya tidak berwujud dan tidak mengakibatkan perpindahan kepemilikan apapun[8]. Jasa yang dimaksud pada sistem adalah segala bentuk jenis layanan yang dapat disewakan kepada konsumen, baik berupa skill maupun berupa penyewaan alat.

Tugas akhir mahasiswa merupakan solusi dari setiap permasalahan yang ada di dalam masyarakat, maka dari itu penting untuk memberitahukan kepada masyarakat bahwa mereka telah memiliki solusi atas permasalahan yang selama ini mereka alami. Hal ini terkait dengan tujuan sistem informasi untuk mendistribusikan informasi yang telah dikumpulkan, diolah, dan disimpan, sehingga informasi dapat menyebar ke seluruh lapisan masyarakat[4]. Namun kurangnya serta manualnya media promosi dan diseminasi menyebabkan kurang luasnya penyebaran informasi.

Dalam bisnis online, maraknya penipuan terkait kualitas dan kuantitas produk menyebabkan timbulnya keraguan oleh masyarakat dalam memilih media belanja yang tepat. Masyarakat juga memerlukan suatu jaminan bahwa produk dan jasa yang ditawarkan merupakan produk dan jasa yang berkualitas dan layak untuk digunakan, yang berarti tidak terdapat perbedaan yang signifikan antara kenyataan dan harapan pelanggan terhadap produk dan jasa yang mereka terima[10].

Sistem informasi pengelolaan produk dan jasa pada Universitas Negeri Padang merupakan sistem berbasis web yang menyediakan modul dan layanan pengelolaan promosi, penjaminan kualitas, pemesanan produk dan jasa, data transaksi, penghitungan ongkos kirim, serta manajemen data produk, data jasa, data user, hingga dokumentasi setiap aktivitas yang terjadi di dalam sistem berupa laporan. Sistem ini juga menyediakan layanan bagi pihak luar yang ingin bekerja sama dengan Universitas Negeri Padang dalam memasarkan produk dan jasa yang mereka miliki.

\section{PENDEKATAN PEMECAHAN MASALAH \\ Analisis Dan Perancangan}

Analisis merupakan proses meneliti kebutuhan pengguna informasi (end user) dan menentukan tingkat penampilan sistem yang diperlukan untuk memenuhi kebutuhan[9]. Analisis merupakan fase pertama dalam pengembangan dan pembangunan sistem informasi yang difokuskan 
pada masalah dan persyaratanpersyaratan bisnis[7]. Sedangkan perancangan sistem merupakan proses pengembangan spesifikasi sistem baru berdasarkan rekomendasi hasil analisis sistem. Proses perancangan harus mencakup bagian input, proses dan output secara detail, sehingga tidak ada timpang saat pembuatannya [9].

\section{Analisis Permasalahan dan Solusi}

Analisis permasalahan dan solusi merupakan penganalisisan terhadap permasalahan yang terjadi pada sistem yang sedang berjalan dan solusi yang diberikan untuk menyelesaikan permasalahan tersebut. Berikut analisis permasalahan dan solusi pada sistem:

Tabel 1. Analisis Permasalahan dan Solusi

\begin{tabular}{|c|c|c|}
\hline No. & Masalah & Solusi \\
\hline 1. & $\begin{array}{l}\text { Pada sistem yang sudah ada } \\
\text { sebelumnya belum ada pihak } \\
\text { yang dapat menjamin } \\
\text { kualitas produk/jasa yang } \\
\text { dipasarkan. }\end{array}$ & $\begin{array}{l}\text { Sistem memiliki Quality } \\
\text { Inswrance sebagai pihak yang } \\
\text { berwenang untuk menguji dan } \\
\text { menentukan layak atan tidaknya } \\
\text { suatu produl/jasa untuk } \\
\text { dipasarkan. }\end{array}$ \\
\hline 2. & $\begin{array}{l}\text { Produlk/karya civitas } \\
\text { akademika Universitas } \\
\text { Negeri Padang khususnya } \\
\text { tugas alkhir mahasiswa yang } \\
\text { berupa alat belum } \\
\text { termanfaetkan seluruhnya, } \\
\text { bahkan cenderung tak } \\
\text { terpakai. }\end{array}$ & $\begin{array}{l}\text { Sistem memberikan fasilitas } \\
\text { untuk memasarkan produlk/karya } \\
\text { tugas alkhir mahasiswa, sehingga } \\
\text { masyarakat dapat mengetahui } \\
\text { informasi seputar temuan terbaru } \\
\text { warga UNP dan dapat } \\
\text { menggunakan produk/alat } \\
\text { tersebut sesuai dengan } \\
\text { kebutuhannya. }\end{array}$ \\
\hline 3. & $\begin{array}{l}\text { Kurangnya informasi dan } \\
\text { publikasi mengenai } \\
\text { produl/karya civitas } \\
\text { alkademika lhususnya tugas } \\
\text { alkhir mahasiswa yang telah } \\
\text { berhasil diciptakan dan jasa } \\
\text { yang dapat warga UNP } \\
\text { sediakan. }\end{array}$ & $\begin{array}{l}\text { Sistem menyedialsan informasi } \\
\text { lengksp seputar produk mulai } \\
\text { dari tanggal jadi produk, } \\
\text { kegunaan dan gambaran lengksp } \\
\text { produk, data uji kualitas produk, } \\
\text { foto produl, dan harga produl. } \\
\text { Serta informasi lengkap seputar } \\
\text { jasa mulai dari gambaran lengksp } \\
\text { jasa, prestasi yang pemah dicapai } \\
\text { jasa, foto jasa, jadwal jasa } \\
\text { tersadia, serta hargajasa. }\end{array}$ \\
\hline 4. & $\begin{array}{l}\text { Belum adanya media } \\
\text { promosi produlkjasa } \\
\text { Universitas Negeri Padang, } \\
\text { sehingga menyebablkan } \\
\text { kurang luasnya penyebaran } \\
\text { informasi mengenai } \\
\text { produl/jasa/usaha yang } \\
\text { dimiliki oleh warga UNP, } \\
\text { khusuanya mahasiswa. }\end{array}$ & $\begin{array}{l}\text { Sistem menyediakan media } \\
\text { promosi produl/jasa untuk: } \\
\text { diinformasikan kepada seluruh } \\
\text { masyaralsat yang membutuhkan } \\
\text { produl/jasa sesuai dengan } \\
\text { kebutuhannya. }\end{array}$ \\
\hline 5. & $\begin{array}{l}\text { Masyarakat sulit untuk } \\
\text { menemukan produl/jasa } \\
\text { yang telah tejamin } \\
\text { kualitasnya. }\end{array}$ & $\begin{array}{l}\text { Sistem memberikan jaminan } \\
\text { mutu berdasarkan hasil uji } \\
\text { Quality Inswrance. }\end{array}$ \\
\hline
\end{tabular}

\section{Analisis Prosedur} Analisis prosedur memberikan gambaran tentang jalannya sistem yang akan dibangun. Tujuannya adalah untuk mengetahui lebih jelas bagaimana cara kerja sistem tersebut. Berikut prosedur yang akan dibangun:

Tabel 2. Analisis Prosedur

\begin{tabular}{|c|c|c|c|c|}
\hline $\mathbf{N}$ & Aktivitas & Prosedur & $\begin{array}{c}\text { User } \\
\text { Terkait }\end{array}$ & $\begin{array}{l}\text { Dokumen } \\
\text { Terkait }\end{array}$ \\
\hline 1. & $\begin{array}{l}\text { Pendaftaran } \\
\text { Supplier }\end{array}$ & $\begin{array}{l}\text { Pemilik prodiul/jasa } \\
\text { mendaftarkan dirinya } \\
\text { sebagai Supplier pada } \\
\text { sistem. }\end{array}$ & $\begin{array}{l}\text { Publik, } \\
\text { Pengelola } \\
\text { Sistem }\end{array}$ & $\begin{array}{l}\text { Formulir } \\
\text { Pendaftaran }\end{array}$ \\
\hline 2. & $\begin{array}{l}\text { Pendiaftaran } \\
\text { Produlv/Jasa }\end{array}$ & $\begin{array}{l}\text { Supplier mendaftarkan } \\
\text { produk jasa miliknya. }\end{array}$ & $\begin{array}{l}\text { Pengelola } \\
\text { Produl;, } \\
\text { Pengelola } \\
\text { Jasa, } \\
\text { Supplier. } \\
\text { Pengelola } \\
\text { Sistem } \\
\end{array}$ & $\begin{array}{l}\text { Thlan / Data } \\
\text { Produl/Jasa }\end{array}$ \\
\hline 3. & $\begin{array}{l}\text { Notifilicasi } \\
\text { Pendaftaran } \\
\text { Produlu/Jasa } \\
\end{array}$ & \begin{tabular}{|lr} 
Menerima & notifikasi \\
berups & adanya \\
pendaftaran produlv jasa
\end{tabular} & $\begin{array}{l}\text { Ouality } \\
\text { Dnswrance }\end{array}$ & $\begin{array}{l}\text { Informasi } \\
\text { Pendaftaran } \\
\text { Produl/Jasa }\end{array}$ \\
\hline 4. & $\begin{array}{l}\text { Penentuan } \\
\text { Jadwal } \mathrm{Uji}^{-}\end{array}$ & $\begin{array}{l}\text { Menentulkan jadwal uji } \\
\text { kualitas produlb } \mathrm{jasa}\end{array}$ & $\begin{array}{l}\text { Ovality } \\
\text { Dnswrance }\end{array}$ & $\begin{array}{l}\text { Jadwal Uji } \\
\text { Kualitas }\end{array}$ \\
\hline 5. & $\begin{array}{l}\text { Penerimaan } \\
\text { Jadwal Uji }\end{array}$ & $\begin{array}{l}\text { Menerima jadwal } u j i \\
\text { kualitas produly } j \text { asas }\end{array}$ & $\begin{array}{l}\text { Supplier, } \\
\text { Pengelola } \\
\text { Sistem }\end{array}$ & $\begin{array}{l}\text { Informasi } \\
\text { Jadwal } \mathrm{Ujj}_{\mathrm{ji}}\end{array}$ \\
\hline 6. & $\begin{array}{l}\text { Verifilsasi } \\
\text { Produlb/Jasa }\end{array}$ & $\begin{array}{l}\text { Memberikan tindalkan } \\
\text { berupa izin atan } \\
\text { penolaksan terhadas suatu } \\
\text { produlv'jasa yang telah } \\
\text { diuji. }\end{array}$ & $\begin{array}{l}\text { Quality } \\
\text { inswrance }\end{array}$ & $\begin{array}{l}\text { Data } \\
\text { verifikasi } \\
\text { produly } / \text { jasa }\end{array}$ \\
\hline 7. & $\begin{array}{l}\text { Pendaftaran } \\
\text { Member }\end{array}$ & $\begin{array}{l}\text { Pengguna mendaftarkan } \\
\text { dirinya sebagai member } \\
\text { pada sistem. }\end{array}$ & $\begin{array}{l}\text { Mesmber, } \\
\text { Pengelola } \\
\text { Sistem }\end{array}$ & $\begin{array}{l}\text { Formulir } \\
\text { Pendaftaran }\end{array}$ \\
\hline 8. & $\begin{array}{l}\text { Mencari } \\
\text { Produlk/Jasa }\end{array}$ & $\begin{array}{l}\text { Melaknulsan pencarian } \\
\text { produlk jasa } r \text { yang } \\
\text { dibutuhlkan berdasarkan } \\
\text { lastegori dan sesuai } \\
\text { dengan jadwal (untuk } \\
\text { jasa) yang tersedia. }\end{array}$ & $\begin{array}{l}\text { Publik, } \\
\text { Member }\end{array}$ & $\begin{array}{l}\text { Informasi } \\
\text { produly/jasa }\end{array}$ \\
\hline 9. & $\begin{array}{l}\text { Mencari } \\
\text { Informasi } \\
\text { Produl } / \text { Jasa }\end{array}$ & $\begin{array}{ll}\text { Mengumpulksan } & \text { aegala } \\
\text { informasi } & \text { terkait } \\
\text { produly jasa } & \\
\end{array}$ & $\begin{array}{l}\text { Publik, } \\
\text { Member }\end{array}$ & $\begin{array}{l}\text { Informasi } \\
\text { produly/jasa }\end{array}$ \\
\hline 10 & Pemesanan & $\begin{array}{l}\text { Melakulsan pemesanan } \\
\text { terhadisp produl/jasa }\end{array}$ & $\begin{array}{l}\text { Publik } \\
\text { Member }\end{array}$ & $\begin{array}{l}\text { Data } \\
\text { Pemesanan }\end{array}$ \\
\hline 11 & $\begin{array}{l}\text { Penerimaan } \\
\text { Pemesanan }\end{array}$ & $\begin{array}{l}\text { a. Menerima } \\
\text { b. Memesanan produl } \\
\text { pemerima } \\
\text { sesuai jadwal jasa }\end{array}$ & $\begin{array}{l}\text { Pengelola } \\
\text { Produlk, } \\
\text { Pengelola } \\
\text { Jasa, } \\
\text { Supplier. } \\
\text { Pengelola } \\
\text { Sistem } \\
\end{array}$ & $\begin{array}{l}\text { Informasi } \\
\text { Pernesanan } \\
\text { produly/jasa }\end{array}$ \\
\hline 12 & $\begin{array}{l}\text { Pengisian } \\
\text { Biodata }\end{array}$ & $\begin{array}{l}\text { Melaksulsan } \\
\text { biodata } \\
\text { pernesan. }\end{array}$ & $\begin{array}{l}\text { Nember, } \\
\text { Publik }\end{array}$ & $\begin{array}{l}\text { Data } \\
\text { Pemesanan }\end{array}$ \\
\hline 13 & $\begin{array}{l}\text { Pengarsipan } \\
\text { Data } \\
\text { Pemesanan }\end{array}$ & $\begin{array}{l}\text { Mencatat data } \\
\text { pernesanan pada tiap-tiap } \\
\text { produly/jasa }\end{array}$ & $\begin{array}{l}\text { Pengelola } \\
\text { produk/jas } \\
\text { a, Supplier }\end{array}$ & $\begin{array}{l}\text { Data } \\
\text { permesanan }\end{array}$ \\
\hline 14 & $\begin{array}{l}\text { Konfirmasi } \\
\text { Pembayaran }\end{array}$ & 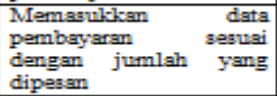 & $\begin{array}{l}\text { Publik, } \\
\text { Member }\end{array}$ & $\begin{array}{l}\text { Data } \\
\text { Pernbayaran }\end{array}$ \\
\hline 15 & $\begin{array}{l}\text { Pengaraipan } \\
\text { Data } \\
\text { Pembayaran }\end{array}$ & $\begin{array}{l}\text { Mencatat seluruh } \\
\text { pembayaran yang terjadi }\end{array}$ & $\begin{array}{l}\text { Pengelola } \\
\text { Produk, } \\
\text { Pengelola } \\
\text { Jasa, } \\
\text { Pengelola } \\
\text { Sistem } \\
\end{array}$ & $\begin{array}{l}\text { Data } \\
\text { Pembayaran }\end{array}$ \\
\hline
\end{tabular}

\section{Analisis User}

Analisis user merupakan proses pendefinisian siapa saja yang terlibat di dalam sistem dan apa-apa saja aktivitas yang bisa dilakukan di dalam sistem. Setiap user memiliki hak akses terhadap dokumen yang 


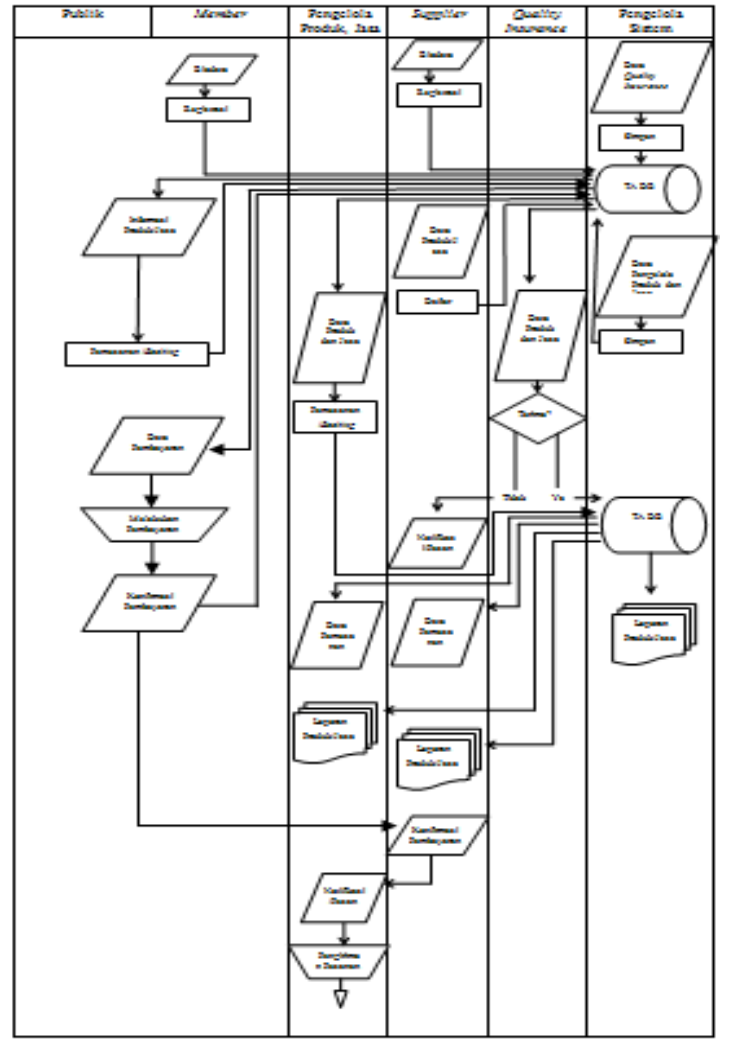

Gambar 3. Diagram Flow-map

\section{Entity Relationship Diagram} (ERD)

Dalam merancang suatu basis data, diperlukan Entity Relationship Diagram (ERD) untuk menggambarkan entitas (aktor) yang berperan dalam sebuah basis data serta hubungan antar aktor-aktor yang berperan tersebut[11]. Berikut rancangan ERD pada sistem:

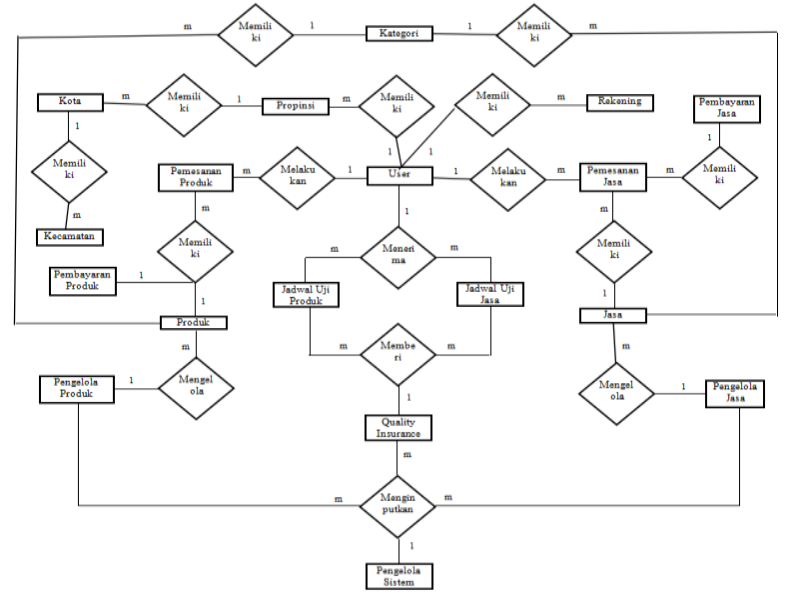

Gambar 4. Entity Relationship Diagram

HASIL DAN PEMBAHASAN

Antarmuka pengguna merupakan tampilan dimana pengguna berinteraksi dengan sistem[7]. Berikut hasil rancangan tampilan (antarmuka pengguna) pada Sistem Informasi Pengelolaan Produk Dan Jasa Berbasis Web Pada Universitas Negeri Padang:

\section{Halaman Utama}

Halaman ini merupakan halaman utama yang akan dilihat oleh setiap user yang membuka alamat website sistem informasi pengelolaan produk dan jasa Universitas Negeri Padang. Tampilan halaman utama ditunjukkan pada gambar berikut: 


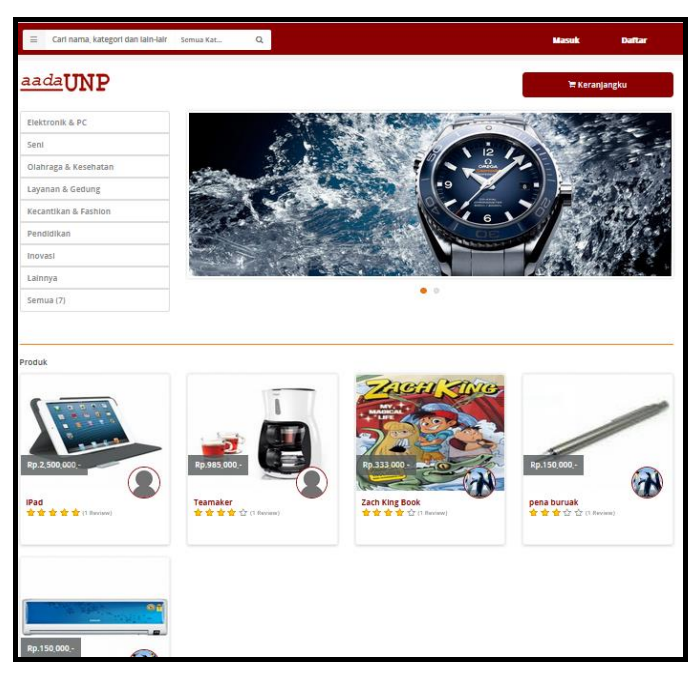

Gambar 5. Tampilan Halaman Utama

Tampilan antarmuka pada suatu sistem haruslah sesuai dengan kebutuhan dan memberikan kemudahan bagi penggunanya[7]. Pada gambar di atas dapat kita lihat bahwa halaman ini menampilkan beberapa produk dan jasa yang diurutkan berdasarkan produk dan jasa yang terbaru. Di bagian sebelah kiri terdapat daftar kategori yang disediakan oleh sistem untuk mempermudah pengguna dalam menemukan produk dan jasa yang diinginkan. Hal ini telah sesuai dengan kebutuhan dan memberikan kemudahan bagi pengguna dalam menemukan produk dan jasa yang diinginkan.

\section{Halaman Login}

Halaman ini merupakan halaman yang digunakan oleh user untuk dapat mengakses halaman sistem sesuai dengan levelnya masing-masing dengan cara memasukkan username dan password dengan benar sesuai dengan username dan password yang telah didaftarkan pada saat registrasi. Pada proses login diterapkan beberapa teknik keamanan yang digunakan untuk menghindarinakan untuk menghindari segala ancaman yang mungkin terjadi [1], yaitu teknik keamanan session untuk membagi hak akses berdasarkan level dan teknik keamanan enkripsi data untuk menyandikan password. Tampilan halaman login dapat dilihat pada gambar berikut:

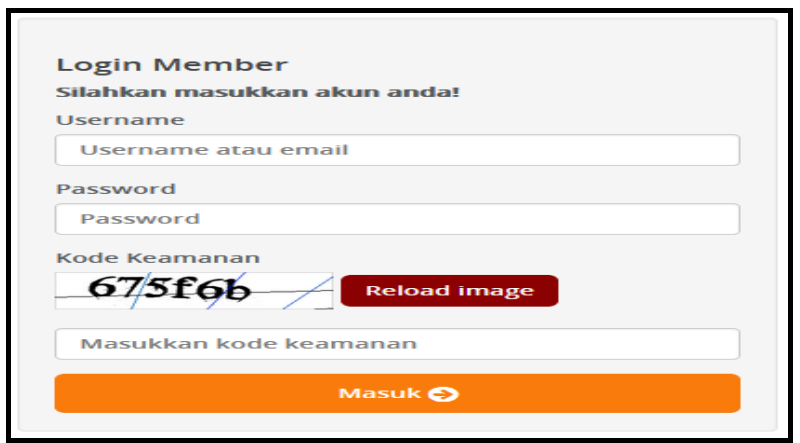

Gambar 6. Tampilan Halaman Login

Pada halaman ini user diharuskan untuk memasukkan kode keamanan yang tampil pada kolom agar dapat mengakses halaman sesuai dengan level masing-masing user.

\section{Halaman Registrasi}

Halaman ini digunakan oleh setiap user untuk mengisi biodata masing-masing user (kecuali pengelola produk/jasa dan Quality Insurance karena yang memiliki hak untuk mengisi biodata pengelola produk/jasa dan Quality Insurance hanyalah pengelola sistem) seperti nama, tempat tanggal lahir, alamat, jenis kelamin, email, dan lain sebagainya. Berikut tampilan halaman registrasi: 


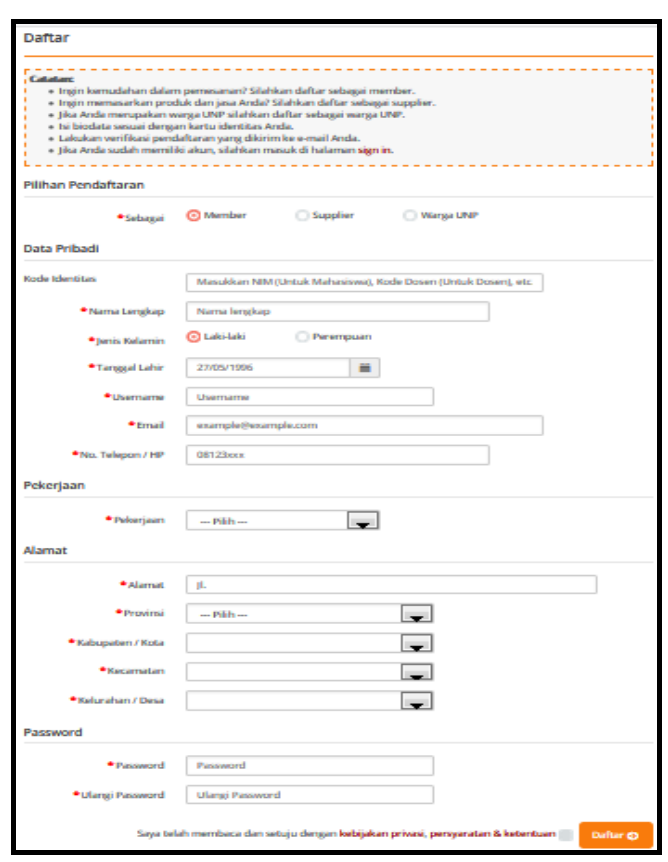

Gambar 7. Tampilan Halaman Registrasi

$$
\begin{aligned}
& \text { Pada gambar di atas } \\
& \text { dapat dilihat bahwa } \\
& \text { pengguna/publik dapat } \\
& \text { menentukan pilihan } \\
& \text { pendaftaran, yaitu sebagai } \\
& \text { member, supplier, atau sebagai } \\
& \text { Civitas UNP. Jika pengguna } \\
& \text { ingin menjualkan } \\
& \text { produk/jasanya pada sistem } \\
& \text { maka harus mendaftar sebagai } \\
& \text { supplier, jika hanya ingin } \\
& \text { melakukan pemesanan maka } \\
& \text { bisa mendaftar sebagai } \\
& \text { member, sedangkan apabila } \\
& \text { pengguna ingin melakukan } \\
& \text { pemesanan dan berstatus } \\
& \text { sebagai civitas akademika UNP, } \\
& \text { silahkan mendaftar sebagai } \\
& \text { civitas UNP. }
\end{aligned}
$$

\section{Halaman Input Data Produk}

Halaman ini digunakan oleh setiap supplier untuk menginputkan data lengkap tentang produk miliknya yang ingin dipasarkan pada sistem. Halaman ini hanya akan tampil pada halaman supplier. Berikut tampilan halaman input data produk pada sistem:

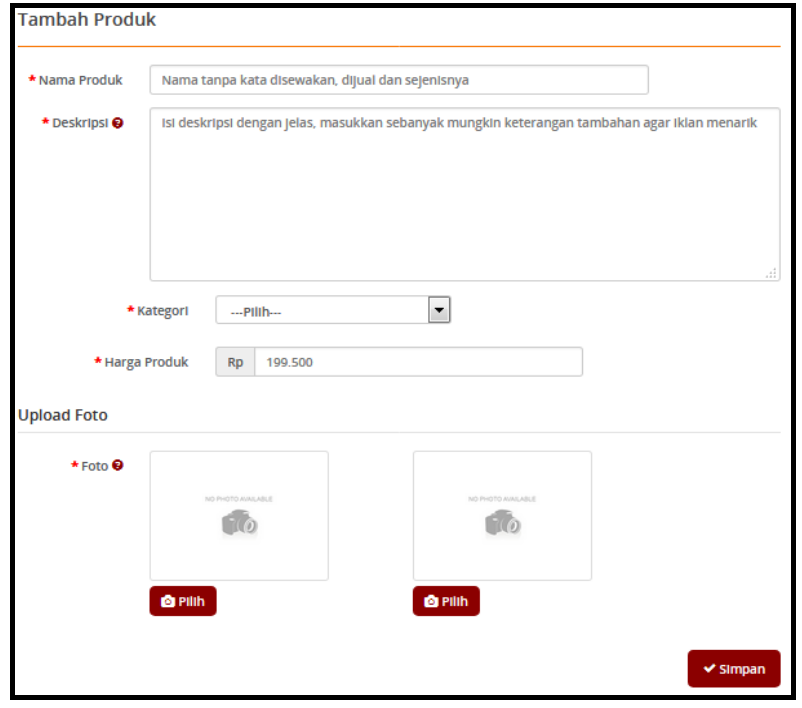

Gambar 8. Halaman Input Data Produk

\section{Seluruh kolom yang} terdapat pada halaman input data produk harus diisi lengkap oleh supplier. Pengguna dapat memasukkan gambar produk sebanyak 2 buah, namun jika gambar yang tersedia hanya ada 1 juga diperbolehkan.

\section{Halaman Input Data Quality Insurance (QI)}

Halaman ini digunakan oleh Pengelola Sistem untuk menginputkan data dan memberikan hak akses kepada Quality Insurance sesuai dengan kebijakan perusahaan. Pengelola Sistem dapat mengelompokkan QI sesuai dengan kategori kemampuannya. Berikut tampilannya: 


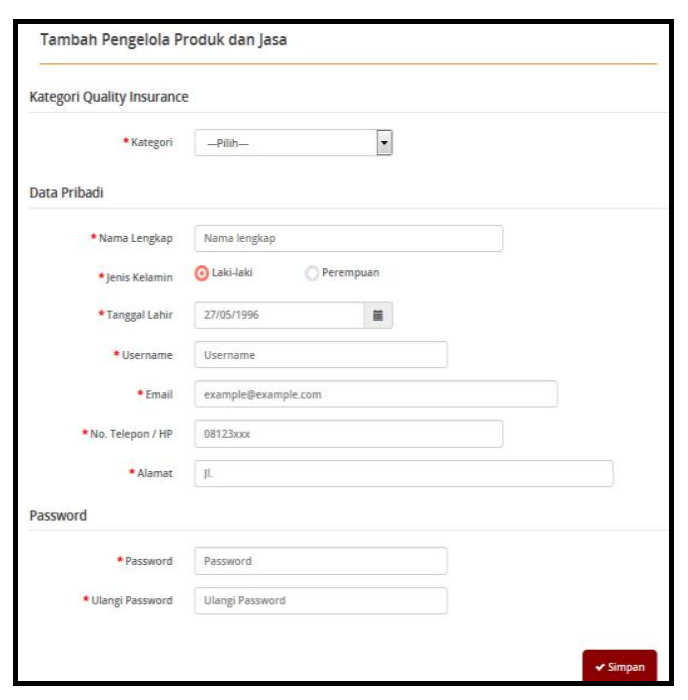

Gambar 9. Tampilan Halaman Input QI

QI ditunjuk sebagai pihak yang bertugas melakukan uji kualitas terhadap suatu produk dan jasa serta memberikan penilaian terhadap kelayakannya. Penjaminan kualitas dilakukan untuk memberikan bukti-bukti untuk membangun kepercayaan konsumen bahwa produk dan jasa yang ditawarkan terjamin kualitasnya[2].

\section{Halaman Input Jadwal Uji Produk}

Halaman ini digunakan oleh seorang Quality Insurance untuk melihat produk dan jasa apa saja yang terdaftar sesuai dengan kategori masing-masing QI. Pada halaman ini, QI dapat menentukan jadwal uji produk dan jasa dengan cara menekan tombol kalender pada layar. Berikut tampilannya;

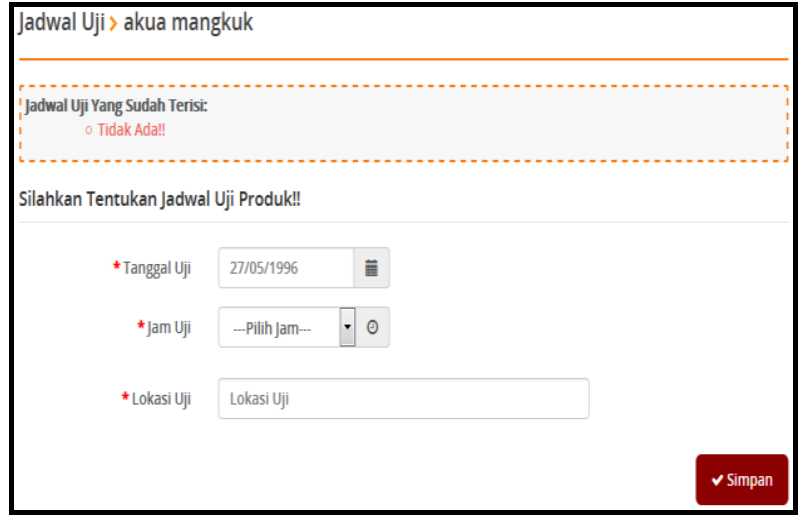

Gambar 10. Halaman Input Jadwal Uji

Pada halaman ini terdapat sebuah catatan yang menunjukkan jadwal uji yang telah diisi sebagai pertimbangan terhadap QI untuk menentukan jadwal uji selanjutnya. QI harus mengisi seluruh form terutama lokasi uji agar informasi yang diterima oleh supplier jelas. Hal ini telah sesuai dengan syarat sistem informasi terkait reservasi dengan layanan penentuan jadwal, yaitu informasi mengenai jadwal beserta kelengkapan lainnya secara jelas dan lengkap[3].

\section{Halaman Pemesanan Produk}

Halaman ini digunakan oleh user untuk memesan produk yang diinginkan. Pemesanan dapat dilakukan melalui dua pilihan, yaitu pemesanan langsung, dan pemesanan member. Berikut tampilan untuk pemesanan langsung:

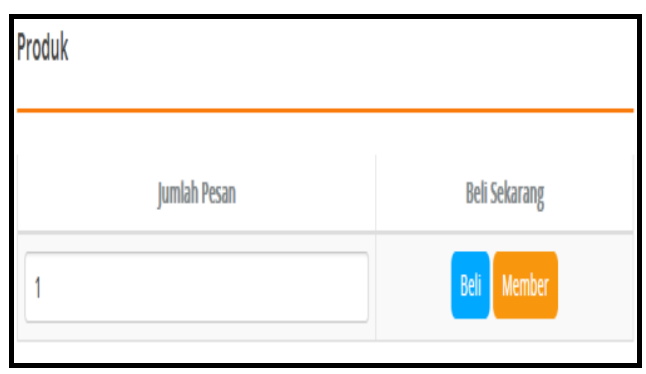

Gambar 11. Halaman Pemesanan Produk 
Pada pemesanan langsung, pemesan tidak perlu melakukan login. Pemesan diwajibkan untuk mengisi datadata seperti nama, e-mail, telepon, dan sebagainya. Hal ini dapat dilakukan dengan menekan tombol 'Beli'. Berbeda dengan pemesanan langsung, pemesanan member membutuhkan aktivitas login untuk memulai pemesanan, yaitu dengan menekan tombol 'Member'.

\section{Halaman Pemesanan Jasa}

Halaman ini digunakan oleh user untuk melakukan pemesanan terhadap jasa yang dipasarkan pada sistem. Sistem menyediakan data untuk segala informasi terkait jadwal, pemesanan, serta informasi lainnya[3]. Konsumen yang melakukan pemesanan jasa dapat menentukan jadwal pemesanan serta lokasi yang diinginkan. Pengelolaan jadwal disediakan untuk mencegah tumpang tindihnya jadwal pemesanan. Sama halnya dengan pemesanan produk, untuk melakukan pemesanan jasa seorang pemesan juga memiliki dua pilihan, yaitu pemesanan langsung dan pemesanan member. Berikut tampilan halaman pemesanan member:

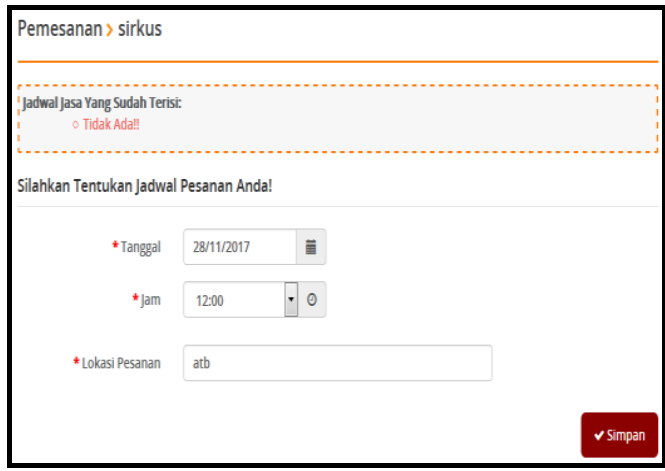

Gambar 12. Halaman Pemesanan Jasa

\begin{abstract}
Pada halaman ini terdapat catatan yang memperlihatkan jadwal penyewaan jasa yang telah dipesan untuk mempermudah konsumen dalam menentukan jadwal penyewaan. Untuk pengisian lokasi pesanan, konsumen diharuskan untuk mengisi lokasi secara rinci dan jelas.
\end{abstract}

9. Halaman Pembayaran Produk Halaman ini digunakan oleh member/publik untuk melakukan konfirmasi pembayaran atas produk yang telah dipesannya. Berikut adalah tampilannya:

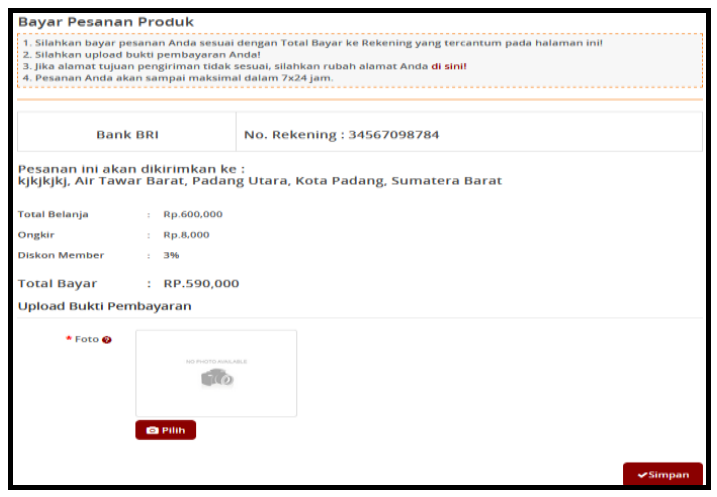

Gambar 13. Konfirmasi Pembayaran

Pada halaman ini terdapat beberapa data yang diperlukan dalam pengiriman produk, yaitu nomor rekening Aadaunp, alamat pesanan, rincian pembayaran, serta bagian upload bukti pembayaran. Biaya pengiriman akan dihitung berdasarkan alamat tujuan. Untuk diskon member sebelumnya telah ditentukan oleh perusahaan dan akan diinputkan oleh Pengelola Sistem. Setelah konfirmasi pembayaran dilakukan oleh konsumen, pengelola produk/jasa akan melakukan konfirmasi pembayaran. Apabila 
pembayaran telah dikonfirmasi, supplier akan mendapatkan notifikasi pemesanan dan harus segera menyediakan pesanan.

10. Halaman Laporan Transaksi

Halaman ini digunakan oleh pengelola sistem untuk melihat seluruh transaksi yang terjadi pada sistem. Suatu sistem informasi haruslah menyediakan kebutuhan pihak pengguna dalam bentuk informasi lengkap beserta laporan yang terkait[11]. Pengelola sistem dapat melakukan aksi cetak terhadap laporan tersebut. Berikut tampilannya pada halaman laporan transaksi:

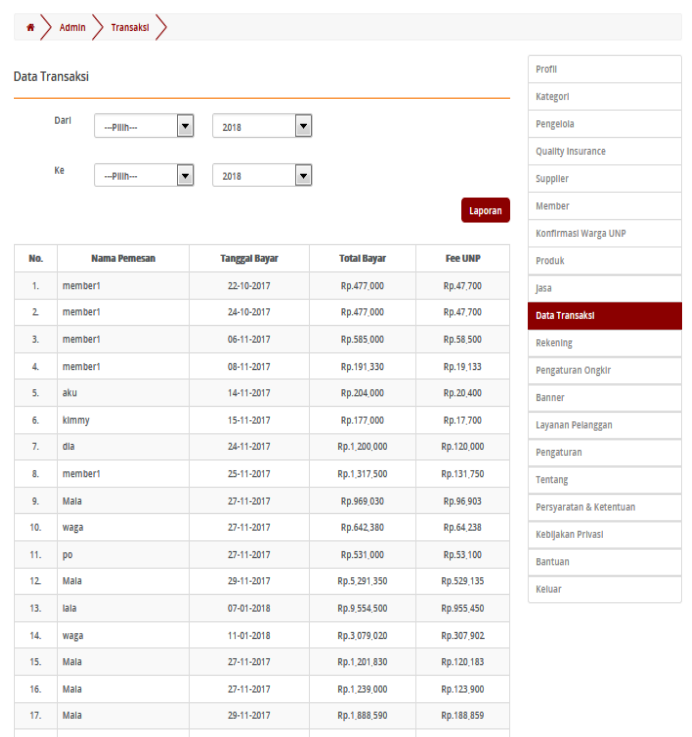

Gambar 14. Halaman Laporan Transaksi

Pada halaman ini terdapat beberapa informasi mengenai seluruh transaksi yang dilakukan pada sistem, diantaranya adalah nama pemesan, tanggal pembayaran, total pembayaran, serta fee yang akan didapatkan oleh Universitas Negeri Padang sesuai dengan ketentuan yang telah ditetapkan. Pengelola sistem dapat melakukan filter terhadap laporan sesuai dengan kebutuhan, dengan cara melakukan pengaturan bulan dan tahun pada bagian atas halaman.

\section{Halaman Cetak Laporan Transaksi \\ Seperti yang telah} dibahas pada poin sebelumnya, selain dapat melihat laporan transaksi, seorang pengelola sistem juga dapat melakukan perintah cetak laporan data transaksi pada sistem. Berikut tampilannya:

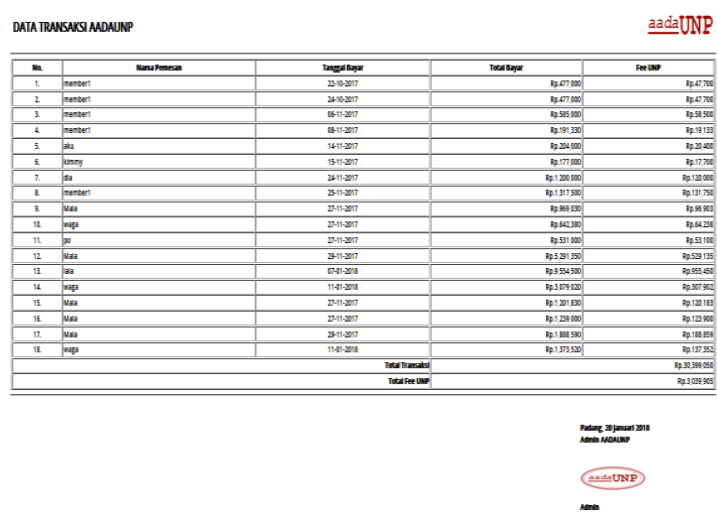

Gambar 15.Cetak Laporan Transaksi

Pada halaman ini, informasi yang akan ditampilkan akan sesuai dengan informasi pada tabel pada halaman laporan transaksi. Apabila pengelola sistem melakukan filter pada halaman laporan transaksi, maka yang akan tampil akan sesuai dengan tabel pada halaman tersebut.

\section{KESIMPULAN}

Berdasarkan

hasil

perancangan sistem informasi pengelolaan produk dan jasa berbasis web pada Universitas Negeri Padang, dapat disimpulkan sebagai berikut:

1. Dengan pemanfaatan bahasa pemrograman PHP menggunakan Framework 
Codeigniter

telah

dikembangkan sebuah Sistem Informasi Pengelolaan Produk Dan Jasa Berbasis Web pada Universitas Negeri Padang.

2. Sistem Informasi ini dapat digunakan untuk menyebarkan informasi seputar temuantemuan terbaru warga Universitas Negeri Padang.

3. Dengan adanya sistem informasi pengelolaan produk dan jasa dapat memberikan kemudahan dalam mempromosikan produk dan jasa yang dihasilkan oleh Universitas Negeri Padang.

\section{Saran}

Berikut saran-saran yang diberikan oleh penulis setelah merancang dan membangun sistem informasi ini:

1. Dalam pengembangan selanjutnya, diharapkan sistem informasi ini dapat menyediakan layanan pemesanan hotel.

2. Notifikasi pada sistem ini hanya menggunakan notifikasi angka pada menu pada akun masing-masing, maka pada pengembangan selanjutnya diharapkan notifikasi dapat dilakukan melalui e-mail atau SMS.

\section{DAFTAR PUSTAKA}

[1] Abdul Kohar. 2014. Ancaman Keamanan pada Sistem Informasi Manajemen Rumah Sakit. Yogyakarta: Universitas Islam Indonesia.

[2] Alfi Arif. Quality Assurance dengan metode Quality Function Deployment: Konsep Implementasi Pada Institusi Perguruan Tinggi. Jember: Universitas Jember (artikel ini diakses tanggal 06 Februari 2018).
[3] Anton Setiawan Honggowibowo dan Titien Sediartie. 2005. Sistem Reservasi Pesawat Terbang Berbasis Web. Seminar Nasional Aplikasi Teknologi Informasi

[4] Erwantoni. 2016. Analisis dan Perancangan Sistem Informasi Penjualan dan Jasa Perbaikan Komputer Berbasis Web pada IPTEK Komputer Betara Kabupaten Tanjung Jabung Barat. Jambi: STIKOM Dinamika Bangsa Jamabi.

[5] Fandy Tjiptono. 1997. Strategi Pemasaran. Yogyakarta: Penerbit Andi.

[6] Hamim Tohari. 2014. Astah (Analisis serta Perancangan Sistem Informasi melalui Pendekatan UML. Yogyakarta: Andi Offset.

[7] Hanif Al Fatta. 2007. Analisis dan Perancangan Sistem Informasi untuk Keunggulan Bersaing dan Organisasi Modern. Yogyakarta: Penerbit Andi.

[8] M. Mursid. 2010. Manajemen Pemasaran. Jakarta: Bumi Aksara.

[9] Mohammad Subhan. 2012. Analisa Perancangan Sistem. Jakarta: Lentera IImu cendekia

[10] Rambat Lupiyoadi. 2014. Manajemen Pemasaran Jasa (Edisi 3). Jakarta: Salemba Empat.

[11] Zulpadli. 2016. Sistem Informasi Peta Digital Lokasi Sarana Prasarana Olahraga Provinsi Sumatera Barat. Padang: UNP. 